\title{
Balancing Economy and Ecology: Building toward Environmental Protection, I945-I970
}

From the GDR's founding in 1949, the tension between economy and ecology was an inescapable conundrum for the ruling Socialist Unity Party (SED). A product of Cold War hostility between the Soviet Union and the western Allies, the GDR's right to exist was uncertain and the SED's domestic legitimacy in question. The East German leadership therefore worked to build credibility at home and abroad by rebuilding industry that had been destroyed in the Second World War. As a result, nature - and making use of limited natural resources - figured centrally in plans for communists to consolidate power in eastern Europe, and especially in the GDR. The SED determined that a strong economy was necessary to win over reluctant East Germans who could readily observe a liberal democratic model of government and reconstruction to the west. The East German economy did experience significant growth (though it fell short of the FRG's) in its first few decades, a success that drove planners to set higher production norms. ${ }^{\mathrm{I}}$ Not everyone agreed with this exploitation of nature for the sake of industry, but such arguments gained little resonance in the first postwar decades as the GDR emerged from the ashes. ${ }^{2}$

Nevertheless, by the 1960s, this "smokestack industrialization" model for rebuilding also undeniably devastated the environment, leading to a reckoning in the GDR. ${ }^{3}$ Pollution from heavy industries, such as mining, industrial agriculture, and chemicals along with other branches of the economy ravaged the environment, productivity, and workers' health. The SED realized the urgency of tackling the pollution and began to

I Charles S. Maier, Dissolution: The Crisis of Communism and the End of East Germany (Princeton, NJ: Princeton University Press, 1997), 83. André Steiner, The Plans that Failed: An Economic History of the GDR (New York: Berghahn Books, 20I0), 70-74.

2 Andreas Dix and Rita Gudermann, "Naturschutz in der DDR: Idealisiert, ideologisiert, instrumentalisiert?," in Natur und Staat. Staatlicher Naturschutz in Deutschland, 1906-2006, eds. Hans-Werner Frohn and Friedemann Schmoll (Bonn: Bundesamt für Naturschutz, 2006), 572-573.

3 Konrad H. Jarausch and Michael Geyer, Shattered Past: Reconstructing German Histories (Princeton, NJ: Princeton University Press, 2003), I6I. 
place more emphasis on the idea that socialism encompassed the workers' physical and geistig, or spiritual, as well as material wellbeing. These ideas had their roots in nineteenth-century German movements. ${ }^{4}$ The SED endeavored to enlist East Germans in this project by drawing on conservation, landscape preservation, and nature recreation. ${ }^{5}$ Party leaders demonstrated their commitment in laws, a new ministry, and mass social organizations. The SED claimed "socialist environmentalism" trusted in rationality, science, and technology to improve nature as well as workers' lives.

Demonstrating a responsibility for the environment was to showcase the GDR's progressiveness, drawing on German traditions of engaging with nature as well as Soviet-style communism. The SED treated the GDR as a "display window" to the west that would also help the embattled state gain diplomatic recognition. ${ }^{6}$ The SED supported increased participation within international conservation organizations, and the state made a number of assurances in pursuit of this objective. At the same time, the GDR sought to distinguish "socialist environmental protection" from similar trends in the west, allegedly offering a superior alternative. ${ }^{7}$ Alongside international work, the GDR deepened relations with other Soviet bloc states to further expert and technological exchanges for economic and environmental purposes. Poland and the GDR faced similar structural pressures and transboundary pollution that motivated the states to collaborate in the 1960s and 1970s. ${ }^{8}$ Through these many efforts, the East German leadership sought to depict the GDR as being on the front lines of environmentalism within the Soviet bloc and beyond.

This chapter argues that the SED embraced nature protection for domestic legitimacy and international recognition, though dedication to economic growth consistently complicated this endeavor. The chapter first traces communist economic policies and nature conservation practices as

4 Thomas M. Lekan, Imagining the Nation in Nature: Landscape Preservation and German Identity, 1885-1945 (Cambridge, MA: Harvard University Press, 2004), 7. John Alexander Williams, Turning to Nature in Germany: Hiking, Nudism and Conservation, I900-I940 (Stanford, CA: Stanford University Press, 2007).

5 Jan Palmowski, Inventing a Socialist Nation: Heimat and the Politics of Everyday Life in the GDR, 1945-I990 (New York: Cambridge University Press, 2009).

${ }^{6}$ Edith Sheffer, Burned Bridge: How East and West Germans Made the Iron Curtain (New York: Oxford University Press, 20II), 64.

7 Sandra Chaney and Rita Gudermann, "The East's Contribution to International Conservation Part I," Environmental Policy and Law 40, no. 2-3 (April 20I0), I2I.

8 Romuald Olaczek, "Konserwatorska Ochrona Przyrody w Polsce - Osiagnięcia, rozczarowania, oczekiwania," in Problemy Ochrony Polskie Przyrody, eds. Romuald Olaczek and Kazimierz Zarzycki (Warsaw: Polish Scientific Publishers, 1988), 87. 
well as the tensions between them after the Second World War, placing the GDR in a common central European context of rebuilding. The GDR claimed using science and technology could create a rational, technocratic future that both relied on and protected nature to construct socialism for the East German people. ${ }^{9}$ Next, the chapter examines the sources and effects of pollution, much of which was documented in a comprehensive prognosis report in 1968 that forced the SED to confront the disaster. The SED importantly reached a turning point that year when it codified the right environmental protection in the new constitution. Finally, this chapter situates the SED's actions amid growing environmental awareness on both sides of the Iron Curtain in the late 1960s and early 1970s, revealing entanglements across central Europe and beyond. The SED espoused environmental protection at a moment when fears about pollution, consumption, and the future gripped leaders and citizens around the world. The GDR therefore attempted to construct a distinct approach to nature that balanced economic priorities with environmental protection under socialism.

\section{Constructing Socialism, Conscripting Nature}

After the Second World War, Germany was divided into four zones of occupation, with the Soviets controlling the zone that became the GDR in 1949. The Soviet-backed SED knew from its founding in 1946 that its most pressing tasks were to win over a reluctant population, and after 1949, to legitimize the GDR's existence. ${ }^{\mathrm{IO}}$ As with other Soviet satellite states, rebuilding the economy to keep up with western European recovery proved critical to pacifying discontented peoples. To do so, the Soviet bloc states heavily relied on a smokestack industrial model that intensively used limited natural resources to increase its production, leading to extensive pollution. Yet nature served more than one purpose under communism. Both East German and Polish authorities used mass social organizations to engage with their populations, and later to strengthen ties between them. The SED in particular relied on voluntary associations, such as the Cultural League and National Front, to foster traditions of Heimat preservation and nature conservation to inculcate a new sense of national identity. ${ }^{\text {II }}$ From the GDR's outset, the SED struggled to navigate employing nature for economic purposes while also practicing conservation for the benefit of the people.

9 Dolores Augustine, Red Prometheus: Engineering and Dictatorship in East Germany, I945-199o (Cambridge, MA: MIT Press, 2007), xi-xii.

Io Palmowski, Inventing a Socialist Nation, I-4. II Ibid., I49-I53. 
Constructing socialism on a Stalinist model meant transferring the ownership of resources and means of production to the state and centrally planning the economy based on heavy industry. In the GDR, nationalization began under Soviet occupation, expropriating land from former Nazis, and intensified in the I95Os as the SED consolidated power. ${ }^{12}$ The Soviets directly and indirectly dictated a smokestack industrialization or socialism to mine coal and produce steel in large quantities for rebuilding infrastructure and general industry. ${ }^{13}$ The SED also expanded the chemical industry, which produced fertilizers and pesticides that were crucial to the industrialization and mechanization of East German agriculture. These industries witnessed unexpected successes and production grew tremendously in the first years. ${ }^{\mathrm{I}}$ By the end of the I950s, wages had risen by more than seventy percent, too. ${ }^{15}$ Yet economic growth came at the expense of the natural environment. The SED paid little attention to how these products were made or the impact they had on nature. Concerns primarily surfaced in the context of planning the use of resources to fulfill the Plan, and ideologically to serve the construction of socialism.

Across the Soviet bloc, satellite states also worked to construct smokestack industrial economies to rebuild after the Second World War. Poland, having been decimated over the course of six years of German and Soviet occupation, experienced similar pressure for economic growth after the War. ${ }^{16}$ Warsaw lay in rubble, while other industrial cities like Wrockaw (Breslau) fared nominally better. ${ }^{17}$ Stalinist policies in the immediate postwar years sparked the rapid expansion of heavy industry with a focus on energy-intensive plants and massive coal-burning facilities, but little room was left for other products such as consumer goods. The coalmining region of Silesia provided the cheap energy required for massive steel production. Poland simultaneously encountered difficulties associated with urbanization, such as housing shortages, insufficient water supply, and issues with sewage treatment. ${ }^{18}$ Even as the

${ }^{12}$ Steiner, The Plans that Failed, 26-28.

${ }^{13}$ Konrad H. Jarausch, "Beyond Uniformity: The Challenge of Historicizing the GDR," in Dictatorship as Experience: Towards a Socio-Cultural History of the GDR, ed. Konrad H. Jarausch (New York: Berghahn Books, 1999), II.

I4 Maier, Dissolution, 83-85. Is Steiner, The Plans that Failed, 90.

I6 Padraic Kenney, Rebuilding Poland: Workers and Communists, 1945-1950 (Ithaca, NY: Cornell University Press, 1997), 245. Antoni Z. Kaminski and Bartłowmiej Kaminski, "Road to 'People's Poland': Stalin's Conquest Revisited," in Stalinism Revisited: The Establishment of Communist Regimes in East-Central Europe, ed. Vladimir Tiseameanu (New York: Central European University Press, 2009), I96-198.

${ }^{17}$ Kenney, Rebuilding Poland, I4.

I8 Barbara Hicks, Environmental Politics in Poland: A Social Movement between Regime and Opposition (New York: Columbia University Press, 1996), 37-38. 
Polish authorities prioritized coal and steel, the plants and machinery were aging, or in other instances, dismantled and taken back to the Soviet Union. ${ }^{19}$ The absence of new technology or emissions controls set the stage for economic - and environmental - challenges moving forward. ${ }^{20}$

The GDR's lack of significant reserves and battered infrastructure led to a strict regulation of natural resources in addition to reliance on other Soviet bloc states. Postwar borders meant that Silesia's rich coal deposits that had been part of Germany now belonged to Poland, while Germany's major coalmining region, the Ruhr, lay in the western zones. ${ }^{2 \mathrm{I}}$ These border changes left Soviet and East German authorities with a less efficient and highly polluting type of coal known as lignite, or brown coal, as the only domestically available form of energy. This situation obliged the East German state to both extensively mine lignite as well as to rely on Polish coal deliveries through the 1950s and 1960s. Frequent delays in Polish coal production then reverberated throughout the Soviet bloc as importing countries, such as the GDR, faced shortages. ${ }^{22}$ East German officials also frequently lamented that the GDR was one of the water-poorest countries in the world, which hindered economic growth. ${ }^{23}$ The need to secure water for industrial production and domestic consumption led East German officials to adopt numerous conservation measures. ${ }^{24}$ The GDR's physical constraints, mode of rebuilding, and dependence on other communist states placed many demands on East German nature.

Despite economic necessities, the SED nodded at preserving nature in the I949 constitution and in the GDR's ministries and in party organizations. By the I950s, the GDR's policies rested on three pillars: state nature conservation, party-controlled voluntary organizations, and scientific research. ${ }^{25}$ This tactic drew on a German tradition of scientifically observing and altering nature,

I9 Peter Polak-Springer, Recovered Territory: A German-Polish Conflict over Land and Culture, I9I9-I989 (New York: Berghahn Books, 2015), I85-186.

${ }^{20} \mathrm{BStU}$ MfS ZKG/I43IO, Helmut Schreiber, "Umweltschutz in sozialistischen Ländern: Das Beispiel des oberschlesischen Industriegebietes in der Volksrepublik Polen," (Berlin: Internationales Institut für Umwelt und Gesellschaft, September 1984), 27.

${ }^{21}$ Norman Naimark, The Russians in Germany: A History of the Soviet Zone of Occupation, 1945-1949 (Cambridge, MA: Harvard University Press, 1995), Io.

22 Open Society Archive (OSA), Item No. I0308/56, "Lack of Polish Coke Threatens East German Production Plans," November I0, I956.

${ }^{23}$ Robert Haveman Gesellschaft (RHG) SWV 02/O2, "Möglichkeiten einer ökologischen Modernisierung des Energiesektors der DDR.”

${ }^{24}$ Hermann Behrens, "Rückblicke auf den Umweltschutz in der DDR seit 1990," in Umweltschutz in der DDR: Analysen und Zeitzeugenberichte, Band I: Rahmenbedingungen, eds. Hermann Behrens and Jens Hoffmann (Munich: Oekom, 2008), I5. Formally, the "Law for the Protection, Use, and Maintenance of Water and Protection against Flooding," passed on April 17, 1963.

25 Dix and Gudermann, "Naturschutz in der DDR," 546-547. 


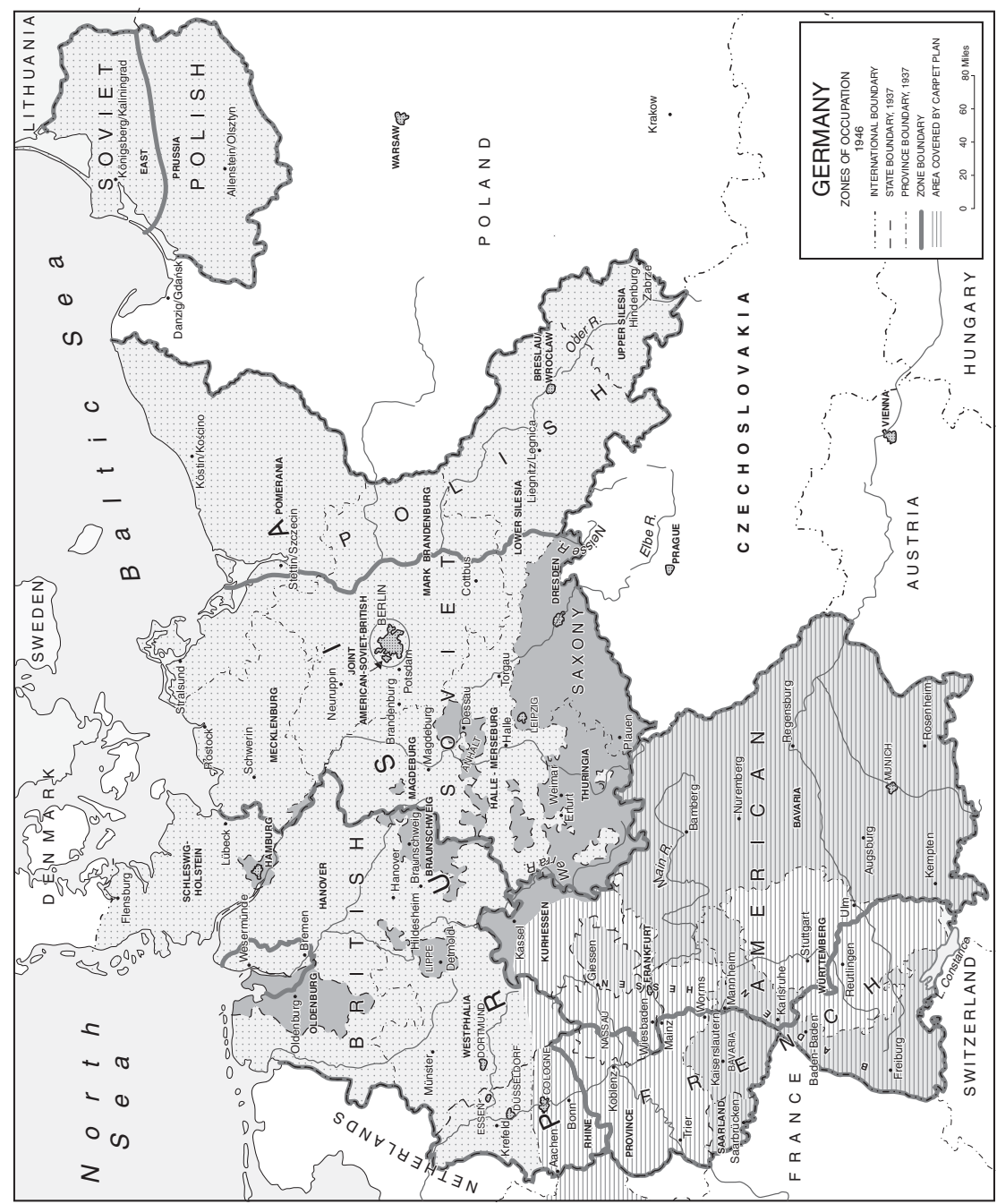

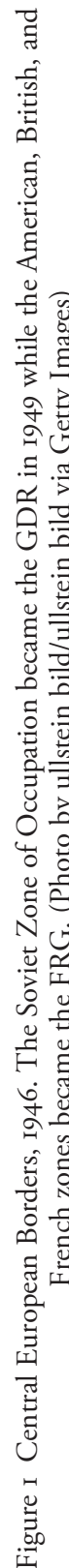


such as through forest management, while also romanticizing the landscape and imbuing it with cultural and national significance. ${ }^{26}$ The constitution turned over ownership of natural resources and products of mining, iron and steel manufacturing, and the energy industry to the state, which was to oversee them in the interest of all East Germans. ${ }^{27}$ The constitution also safeguarded against abuse in distributing and using the land, which the SED institutionalized through placing nature protection in the hands of the Ministries for Agriculture and Forestry as well as People's Education. ${ }^{28}$

The SED further engaged with nature through the party-controlled mass social organization called the Cultural League and a research institute. The Cultural League incorporated already existing voluntary conservation associations and channeled them in approved directions. The Cultural League relied on established ideas about nature and Heimat. In Germany, outdoor pastimes, such as hiking, maintaining natural landscapes and monuments, and nudism, coevolved with these notions, and the SED mobilized them to gain popularity. ${ }^{29}$ Moreover, the state founded the Institute for Landscape Research and Nature Conservation (ILN) in Halle. Under the direction of Hermann Meusel, the institute adopted the conception of "landscape organism," which viewed species' health in connection to both their surroundings and their genetics. ${ }^{30}$ This more integrated approach stood in contrast to economic planners' view of nature as primarily a means of supporting industry.

Conservation and Heimat organizations under the SED's control were crucial to boosting credibility, and the party sought to control them in the name of building socialism. The SED relied on the National Front, which was the umbrella for all mass organizations, including political parties and the trade union. The National Front presented a façade of democracy and a pluralistic society, but in reality the SED held the reins. In terms of nature protection, the National Front coordinated small-scale campaigns, mostly local beautification and cleanup projects. East Germans were encouraged to join these activities out of love for their homeland and construct a socialist Heimat. ${ }^{3 \mathrm{I}}$ This new understanding of Heimat was to be distinct from the Nazi and bourgeois pasts as well as from the FRG, which the SED

26 Lekan, Imagining the Nation in Nature, 7.

27 Verfassung der Deutschen Demokratischen Republik vom 7. Oktober 1949, Artikel 25.

28 Ibid., Artikel 26.

29 Williams, Turning to Nature in Germany; Palmowski, Inventing a Socialist Nation.

3o Scott Moranda, The People's Own Landscape: Nature, Tourism, and Dictatorship in East Germany (Ann Arbor, MI: University of Michigan Press, 20I4), 59.

${ }^{31}$ Palmowski, Inventing a Socialist Nation, I7, I49-I5O. 
considered a continuation of fascism. A socialist Heimat embraced the SED's ideals of anti-fascism, social unity, socialism, and a planned economy. East German Heimat enthusiasts believed educational and cultural self-improvement were at the heart of both Heimat preservation and socialism. $^{32}$

Within the National Front in the 1950s, the Cultural League more specifically took up nature conservation, having purview over technicaloriented groups. In general, the Cultural League was a collection of associations within the National Front that aimed to reach members of the intelligentsia who might not otherwise identify with working class, communist traditions. ${ }^{33}$ The Friends of Nature and Heimat (Natur- und Heimatfreunde, NHF) was the Cultural League association that promoted conservation-related and often specialized subgroups, such as ornithology, botany, geology, and nature conservation. ${ }^{34}$ Members of the NHF maintained protected lands, monitored the implementation of regulations, and mapped plants and animals. NHF subgroups exchanged information and interests across the Iron Curtain, which the SED nominally permitted. ${ }^{35}$ Cultural League officials complained about ideological indifference on the part of NHF members, and increasing pressure to conform to the ideals of "socialist democracy" broke down those contacts over time.

In Poland, the Polish United Workers' Party's (Polska Zjednoczona Partia Robotnicza, PZPR) similarly supported nature conservation as a mass social effort in the early postwar years, albeit with less enthusiasm than the SED. In 1946, the party swiftly reestablished the Nature Conservation League (Liga Ochrony Przyrody, LOP), which had existed in the interwar period, under communist control. The organization boasted branches in Warsaw, Lublin, and Gdynia (near Gdańsk). ${ }^{36}$ Like the NHF, the LOP attracted scholars, foresters, farmers, and teachers, among others, to its ranks. Yet, in the I950s, nature conservation remained limited to a relatively small set of experts, scientists, and specialists rather than enjoying widespread interest. A decade later that changed as the PZPR intentionally targeted youth to join the LOP as part of larger,

32 Ibid., 26-32. For more on continuity with and rupture from the Third Reich, see Moranda, The People's Own Landscape, 52-59.

${ }^{33}$ Mary Fulbrook, Anatomy of a Dictatorship: Inside the GDR, I949-Ig89 (New York: Oxford University Press, 1995), 60-6I.

34 Willi Oberkrome, "Deutsche Heimat": Nationale Konzeption und regionale Praxis von Naturschutz, Landschaftsgestaltung und Kulturpolitik in Westfalen-Lippe und Thüringen (I9oo-1960) (Paderborn: Ferdinand Schöningh, 2004), 282-283.

35 Dix and Gudermann, "Naturschutz in der DDR," 554-555.

36 "Historia Ligi Ochrony Przyrody," www.lop.org.pl/O_nas, accessed May 3, 202I. 
bloc-wide initiatives to engage with nature. In the initial years of the People's Republic of Poland, though, economic rebuilding and industrialization remained the PZPR's primary objective. ${ }^{37}$

From a legal perspective, the SED adopted the 1954 Nature Conservation Law and distanced the GDR - on paper if not in personnel or substance - from the Nazi past. Eliminating the earlier law that the Third Reich had passed in 1935, the new one focused on using nature to build socialism. ${ }^{38}$ In practice, the law was nearly identical to the 1935 version, admitting the economy required invasions into nature's bounty. ${ }^{39}$ The preamble made clear that the preservation of conservation areas and indigenous plants and animals only guarded against the "unwarranted" removal of resources and cautioned that nature should be "destroyed no more than absolutely necessary." ${ }^{\circ}$ Despite privileging economic concerns, the 1954 law still claimed that soil, water, plants, and animals were invaluable to the GDR and that current and future generations of East Germans must protect them. The law also set aside spaces for recreation and reserves for preservation, though it did not treat the whole of the land as something to be protected. Many of the law's more conservationist paragraphs and ideas came from Hermann Meusel, the director of the ILN. ${ }^{4 \mathrm{I}}$ While conservationists thought otherwise, nature as an interconnected system within and outside of conservation areas, however, did not feature prominently in the SED's understanding, especially before 1968. Nevertheless, the SED touted the 1954 law as progressive while the FRG continued to rely on the Nazi-era law well into the 1960s. ${ }^{42}$

Many experts were convinced that scientific and technological innovation would reconcile the "joy and recuperation of all friends of nature" with economic growth. ${ }^{43}$ As in many areas of socialist thought, the SED believed rational solutions could fix all seemingly complicated problems. To this end, officials employed the concept of Landeskultur, which encompassed both improving or molding the land for a specific purpose, such as economic prosperity, and fostering national identity. The GDR

37 Stanley J. Kabala, "The History of Environmental Protection in Poland and the Growth of Awareness and Activism," in Environmental Action in Eastern Europe: Responses to Crisis, ed. Barbara Jancar-Webster (Armonk, NY: M.E. Sharpe, I993), II7-II8.

${ }^{38}$ Oberkrome, "Deutsche Heimat," 20. ${ }^{39}$ Moranda, The People's Own Landscape, 56.

40 BArch DC 20/I/3/230, "Gesetz zur Erhaltung und Pflege der heimatlichen Natur vom I954," July 8 , I954.

4I Oberkrome, "Deutsche Heimat," 329.

42 Dix and Gudermann, "Naturschutz in der DDR," 552.

43 Ibid. BArch DC 20-I/3/7I5, "Prognose: Industrielle Abprodukte und planmäßige Gestaltung einer sozialistischen Landeskultur in der DDR,” 1968, 66. 
sought to formulate a uniquely socialist version of Landeskultur that incorporated both resource management and nature conservation. ${ }^{44}$ The SED planned on technology that would allow the GDR to use resources ever more efficiently, focusing on the "extraction and cultivation of reusable materials in waste products." The GDR's limited supply of fresh water made purifying runoff for reuse crucial, especially for desalinating rivers in the Harz where extensive potash mining made water saltier than the North Sea. ${ }^{45}$ With the goal of advancing technology to overcome physical strictures, the relevant ministries anticipated fulfilling lofty economic goals and at the same time protecting nature for the workers' relaxation and enjoyment.

Landeskultur remained part of planners' mindset as they shifted away from Stalinist practices that emphasized heavy industry and rebuilding in the I96os. This change in economic structuring and priorities offered both opportunities and challenges for environmental practices. In 1963, General Secretary of the SED and leader of the GDR Walter Ulbricht introduced the New Economic System (NES), which decentralized economic planning and management. ${ }^{46}$ The NES initiated industry-based organizations collaborating on major decisions and stressed investment in technologies. ${ }^{47}$ This flexibility focused on "progressive," or high tech, industries and renewed attention to conserving natural resources. Some SED officials, including Erich Honecker, who would oust Ulbricht in 1971, viewed the NES reforms as "unstable," and the SED abandoned it in the aftermath of the Prague Spring. ${ }^{48}$ When the NES failed to perform, Ulbricht shifted to the "Economic System of Socialism" (ESS) in 1967-1968. In it, he aimed to "overtake without catching up" with the west, doubling down on a "scientific-technological revolution" that invested in the chemical industry, engineering, electronics, and automation of the economy to reduce dependence on western goods and imports. ${ }^{49}$ As part of those measures, the SED instigated a different set of environmental hazards, namely intensive industrialization of agriculture, which relied on monoculture farming, fertilizers, and pesticides that changed the rural landscape.

${ }^{44}$ Landeskultur can be translated in a number of ways, including "land stewardship" and "national culture." It built on the longer German tradition of a constructed, cultivated nature as represented in the term Heimat. Moranda, The People's Own Landscape, 63.

45 BArch DC 20/I/3/716, "Nachtrag zur Prognose: Industrielle Abprodukte und planmäßige Gestaltung, einer sozialistischen Landeskultur in der DDR," January 1969. Astrid M. Eckert, "Geteilt aber nicht unverbunden: Grenzgewässer als deutsch-deutsches Umweltproblem," Vierteljahrshefte für Zeitgeschichte 62, no. I (January 2014), 83.

${ }^{46}$ Mary Fulbrook, The People's State: East German Society from Hitler to Honecker (New Haven, CT: Yale University Press, 2005), 37.

${ }^{47}$ Augustine, Red Prometheus, 244-245. $\quad{ }^{48}$ Steiner, The Plans that Failed, IIo.

49 Ibid., II9-I2O. 
New regulations and negotiations with neighboring countries reflected the SED's ongoing attempt to balance inadequate resources for the desired economic growth amid the reforms. In 1963, the GDR introduced a law that centralized water management, weighted domestic water supplies above industry, and required industries to use water more efficiently and reduce runoff. The state eventually added fines for exceeding permitted levels. ${ }^{50}$ A year later, the GDR also passed a regulation protecting the soil from agricultural and forestry-related runoff. ${ }^{\text {SI }}$ In the same period, the GDR signed agreements with Poland and Czechoslovakia about water levels and pollution in shared waterways. The GDR faced downstream pollution from Czechoslovakia and shared water in the Oder River with Poland, which had an impact on East German industry and agriculture. ${ }^{52}$ Thus, the East German leadership acknowledged that environmental issues affected East Germans but constantly worried about their economic impact.

Poland's similar tension in balancing nature and economy underscores commonalities of Soviet-style communism in eastern Europe. Poland's 1949 law on the protection of nature changed the organization and administration, but it did not provide a concrete statement on the "content and implementation of nature conservation." 53 The law also failed to foresee the surge in air and water pollution that Poland's industry would spawn in the following decades, or the effect it would have on the environment. ${ }^{54}$ In 1950, Poland passed its first law creating nature protection areas in industrial regions - including Silesia but it omitted specific emissions levels. ${ }^{55}$ The PZPR wrote environmental laws in the late 1960 s that expanded on early conservation and health-based laws, including air quality laws in 196I and 1966, that provincial (województwo) water management offices administered. ${ }^{56}$ Still, officials regulated water and air quality in a piecemeal fashion with laws of dubious quality. One expert later stated that Poland's problem was "an excess of laws rather than a scarcity." ${ }^{57}$

so BArch DK 5/540, "Gesamtüberblick über die Vereinigung der Gewässer durch Mineralöle und deren Nebenprodukte und Massnahmen zur Verhütung derartiger Verunreinigungen in der DDR,” undated.

${ }^{51}$ BArch DC 20/19IO2, "Grundgedanken für den Diskussionsbeitrag der DDR auf der XXIII. Generalversammlung in Luxemburg," January 20, 197I.

52 BArch DK 4/427, "Vorläufige Tagesordnung der 4. Verhandlung der Regierungsbevollmächtigten DDR/VRP," January 30, I970; “Direktive für das Auftreten des Regierungsbevollmächtigten der DDR und CSSR für die Regelung technischer und wirtschaftlicher Fragen an Grenzwasserläufen," January 30, I970.

53 Olaczek, "Konserwatorska Ochrona Przyrody w Polsce," 89.

54 Hicks, Environmental Politics in Poland, 55.

55 BStU MfS ZKG/I43IO, Schreiber, "Umweltschutz in sozialistischen Ländern," $7 . \quad 56$ Ibid., 7.

57 Michał Kulesza, "Efektywność prawa i administracji w zakresie ochrony przyrody i środowiska, Fragment Raportu KOP PAN na III Kongres Nauki Polskiej," in Problemy Ochrony Polskiej Przyrody, eds. Olaczek and Zarzycki, 23-24. 
The legislation existed on paper but lacked coherence and accountability. As in the GDR, the tension between production, resource conservation, and environmental protection restricted the PZPR's actions.

In the first decades after the Second World War, communist leaders pursued rapid industrialization while also accepting the importance of nature for their citizens. Economic concerns - and the domestic and international legitimacy a strong economy was supposed to ensure typically took precedence over nature conservation. Nevertheless, the two were intrinsically linked. Smokestack socialism relied heavily on intensive extraction of natural resources as well as large amounts of water, compelling economic planners to constantly negotiate between using and conserving them. Moreover, East German leadership in particular recognized the centrality of nature to culture, namely, that preserving it and spending time out of doors held meaning for East Germans. As evidence of pollution from this Stalinist model mounted, these pressures would force the state to reevaluate its relationship with the natural world.

\section{Confronting the Pollution}

By the late I960s, the SED's struggle between "economy and ecology" was obvious; pollution levels were rising in the GDR and spreading beyond the state's borders..$^{58}$ Moreover, East German citizens regarded their conditions, materially and environmentally, with increasing dissatisfaction. Sacrifices that had been tolerated in the name of building socialism in the immediate postwar years now wore on the population. The GDR lagged in comparison to western standards of living, while pollution from fast-paced smokestack industrialization inhibited East Germans' quality of life..$^{59}$ By 1968, the SED held significant and condemnatory data about the crisis. Experts had consolidated their findings in a "prognosis report" that was the thirteenth contribution to Walter Ulbricht's effort to examine the development of all aspects of society. ${ }^{60}$ The pollution cut across all milieus of East German society, eroding health, working, and living conditions, blackening the sky, killing plants and trees, and poisoning the water. This ubiquity drove the SED to confront the escalating predicament and begin shifting its attitude on the environment.

${ }^{8}$ Maier, Dissolution, 91. 59 Steiner, The Plans that Failed, I26.

${ }^{60}$ Tobias Huff, Natur und Industrie im Sozialismus: Eine Umweltgeschichte der DDR (Göttingen: Vandenhoeck \& Ruprecht, 2015), I69. 
The SED's economic planning prioritized the energy and fuel industries, which made up roughly forty percent of industrial investment at the beginning of the 1960 . ${ }^{61}$ The pollution from energy production highlighted the drawbacks of the GDR's only viable energy source, low-grade lignite, which left an indelible mark on the natural and social landscape. The coal was (and is) most easily accessed via open-pit mines, which quickly became an established fixture of the landscape. In the GDR era, the size and scale of the mining eclipsed earlier periods. The enormous mines were physically many times bigger than nearby villages, destabilized the ground, and lowered the local water table. Outside of Leipzig, officials evacuated approximately fifteen villages between I95I and I988 and resettled their 7,800 residents. More than 3,000 of those were moved between 1977 and $1988 .{ }^{62}$ The removal of inhabitants had social consequences, too, uprooting families and communities that had lived there for

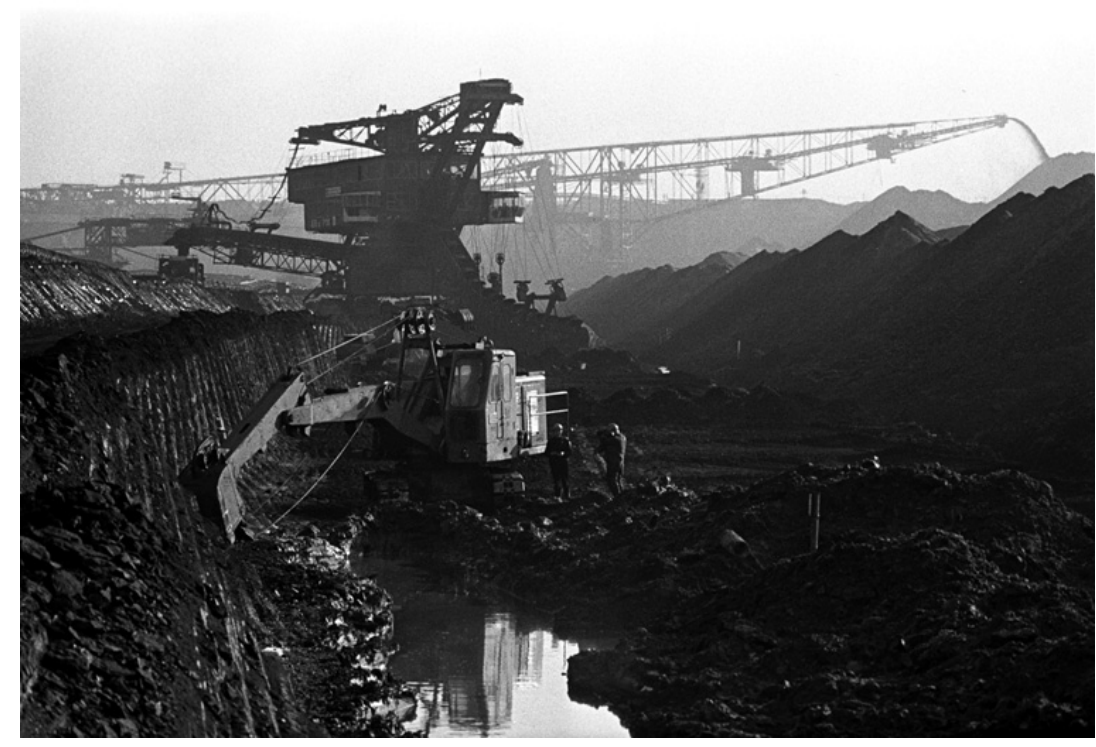

Figure 2 View of the Welzow-Süd open-pit lignite mine in the Cottbus District (Brandenburg) in 1974. (Photo by Erich Schutt/ullstein bild via Getty Images)

${ }^{61}$ Steiner, The Plans that Failed, 73.

${ }^{62}$ Lausitzer und Mitteldeutsche Bergbau-Verwaltungsgesellschaft mbH, "Iо Jahre Sanierungsbergbau mit Tagebaugroßgeräten” (2000), 196. 
centuries and settling them in the new, prefabricated apartment blocks of Leipzig and Halle. ${ }^{63}$

Emissions from the coal beneficiation - or refining - plants harmed local populations by making the air nearly impossible to breathe. Respiratory illnesses such as bronchitis and asthmas plagued residents, especially children and the elderly. The plant in Espenhain (near Leipzig), for example, was originally built during the Third Reich and continued to function - with ever higher production levels - well into the 1980s without renovations or even repairs. According to engineers working there, the operators used two-thirds more coal in the plant's ovens than they had been designed to handle. ${ }^{64}$ The air quality was nearly unbearable. As one report detailed, "These towns are falling apart, drab, and gray, creating an oppressive impression of filth in this poisoned atmosphere. The buildings are black with smoke and soot, and crumbling plaster on the facades ... shows the clear signs of thick layers of dust." ${ }^{65}$ Residents could not leave windows open or hang laundry outside for fear that everything would turn a filthy brown-black color from the soot.

Though beneficiation plants were generally located in coalmining regions, such as Leipzig, Halle and Cottbus, lignite fueled power plants and factories all over the country. Complaints about air pollution stemming from them persisted throughout the GDR's existence. As early as 1968, future environmental minister, Dr. Werner Titel, and other experts acknowledged that coalrelated air pollution had "deep and many-sided detrimental effects" on "humans, animals and plants, and the economy." 66 The prognosis report estimated that the total economic cost already amounted to more than a billion Marks per annum, which the authors assumed would rise with growing production. ${ }^{67}$ The SED attempted to transition to oil and natural gas at various points during the GDR's existence, but the oil shocks of the I970s and the logistical difficulties of converting to natural gas resulted in a renaissance for lignite that started in 1979 and lasted until the state's collapse. ${ }^{68}$

${ }^{63}$ BArch DK 5/4509, "Eingabe - Gisela Merkel, 1974," Eingaben 1974-1975.

${ }^{64}$ RHG ÜG 03, "Eine Reise nach Mölbis, Rötha und Espenheim: Erlebnisse, Fakten und ein Aufruf!" undated.

65 Ibid.

${ }^{66}$ The report was the thirteenth contribution to an order from Walter Ulbricht to examine the development of all aspects of society. Huff, Natur und Industrie im Sozialismus, I69. BArch DC 20/ I9122, "Versuche einer Definition 'Sozialistische Landeskultur' sowie 'Natürlicher Lebensraum,"” Prognosegruppe “Abprodukte und sozialistsiche Landeskultur,” March 4, I968.

67 BArch DC 20-I/3/715, "Prognose: Industrielle Abprodukte und planmäßige Gestaltung einer sozialistischen Landeskultur in der DDR," I968, II. Moranda, The People's Own Landscape, II8-II9.

${ }^{68}$ RHG Th 02/o8, “Aus Umwelt, 4/83, Dr. Cord Schwartau, 'Umweltschutz in der DDR. Zunehmende Luftverschmutzung durch Renaissance der Braunkohle?' Fassung des DIW Wochenberichte, 4/1983." 
The air pollution that Titel and his team identified in the rg6os continued and worsened over the next two decades.

Emissions from power plants, industrial production, and domestic consumption also damaged or killed large tracts of forest across the GDR and in neighboring countries. Sulfur laced the East German lignite and refining processes merely partially removed it. When burned, the sulfur produced acid rain that then devastated urban areas, corroding buildings, monuments, and cars as well as leading to an ecological crisis in the forest. Officials innocuously referred to this phenomenon as "forest damage" (Forstschäden), though in the FRG it was referred to as Waldsterben, or dying of the forest. ${ }^{69}$ Its effects left visible scars in the mountainous Erzgebirge region, along the border to Czechoslovakia. Corpse-like tree trunks and broken-off branches devoid of needles covered entire hillsides and mountain ridges in an area known for its resorts and outdoor recreation.

The Erzgebirge's Waldsterben was intimately tied to transborder pollution between the GDR, Poland, and Czechoslovakia. The acid rain came not only from the GDR but also Czechoslovakia, leading to an agreement between the two countries in the I970s. Seventy-four percent of Czechoslovakia's electro-energy was produced in northern Bohemia, near the East German border, and given prevailing weather patterns, was responsible for a significant portion of the Erzgebirge's acid rain. ${ }^{70}$ Despite being affected by Czechoslovak industry, the GDR's emissions were far higher than the levels of neighboring countries, of which Poland bore the brunt. ${ }^{7 \mathrm{I}}$ By the $198 \mathrm{os}$, reports estimated that nearly half of Poland's air pollution came from the GDR and Czechoslovakia and became a point of diplomatic contention. ${ }^{72}$ The Soviet bloc's heavy reliance on coal caused a myriad of transboundary pollution problems in a closely connected central European context.

69 The more common term for this phenomenon today is Waldsterben, or forest death, but it did not come into common usage until roughly 1980, and then primarily in the West German context. Waldsterben became an important plank in the West German Green Party's platform in the I980s. Even into the late I980s, officials denied that Waldsterben existed in the GDR. For more on the Waldsterben debate in the FRG, see Birgit Metzger, "Erst stirbt der Wald, dann Du!" Das Waldsterben als westdeutsches Politikum (1978-1968) (Frankfurt am Main: Campus Verlag, 2015).

70 Huff, Natur und Industrie im Sozialismus, 226-229.

${ }^{71}$ RHG Th 02/06, Untitled Pamphlet, 1983. BArch DC 20-I/3/715, "Prognose: Industrielle Abprodukte und planmäßige Gestaltung einer sozialistischen Landeskultur in der DDR,” I968, II.

72 Open Society Archive (OSA), Jacek Rostowski, "Environmental Deterioration in Poland," RAD Background Report/169, September 5, 1984. 
In the GDR, the chemical industry, particularly prevalent in the area around Bitterfeld, Halle, and Merseburg known as the Chemical Triangle, further deteriorated the environment. Because the GDR had limited natural resources, SED officials sought to make up for shortages through science and technology to use materials more efficiently and to produce synthetic ones when necessary. This faith in science and technology prevailed in the chemical industry to such an extent that it even had its own ministry and produced everything from photo-processing chemicals to fertilizer and pesticides to household cleaning agents. One of the GDR's most prized chemical projects was plastics, which the SED viewed as an ersatz material for almost anything, including wood in furniture and pottery for tableware. ${ }^{73}$ In the late 1960 , a report announced that the plastics and elastics division of the chemical industry grew at an incredible rate, especially for a planned economy, of fifteen to twenty percent per annum.$^{74}$

The methods used to produce these goods, however, ravaged the natural environment and were hazardous in the home. Byproducts and waste were released into the air and into local bodies of water. The air quality deteriorated so badly in the Chemical Triangle that by 1968 experts estimated the GDR lost six million Marks per year from damage caused by emissions. ${ }^{75}$ In these industrialized areas with high concentrations of particulate matter and sulfur dioxide, residents were prone to croup, laryngitis, and other respiratory illnesses. While lay people observed these symptoms anecdotally to their friends and family, officials from the Ministry for Public Health recorded them faithfully in reports. ${ }^{76}$ The air pollution from industrial production compounded two connected sets of issues. First, coal burned to produce the goods generated pollution, and second, byproducts and waste from production degraded the environment. Together, they resulted in widespread health problems, acid rain, corrosion of buildings, and dying vegetation.

Alongside plastics, dyes also posed a range of dangers to consumers and the environment. East German dyes used dangerous heavy metals, such as cadmium, as stabilizers, endangering workers producing the goods and the

73 Rubin, Synthetic Socialism, IO-II.

74 BArch DC 20-I/3/715, "Prognose: Industrielle Abprodukte und planmäßige Gestaltung einer sozialistischen Landeskultur in der DDR,” I968.

75 Ibid. The value of East German currency is difficult to calculate, because, as Steiner puts it, "They were politically distorted by state-set (and corrected) rates of exchange." Steiner, The Plans that Failed, I20. In this context, however, it is more important that the SED was attempting to understand the financial and economic impact of environmental degradation.

76 RHG Th 02/o8, "PSEUDOKRUPP - Krankheitsverlauf und Therapie," undated. 
consumers. Despite being well aware that neighboring Poland and Czechoslovakia banned heavy metals in production, the GDR continued the practice. ${ }^{77}$ The plastics industry also faced a range of alarming problems with many of the goods it produced. For example, after receiving reports of plastic furniture that melted when hot dishes were placed on them, the chemical industry began adding asbestos to improve the heat resistance of these products. Quick fixes, like using asbestos in plastics, meant that East Germans received more consumer goods, as the SED attempted to keep up with rising standards of living in the FRG. Yet these solutions illustrated that the SED's decision-making process hid such difficulties instead of correcting them. ${ }^{78}$

After producing problematic goods, waste from the GDR's many industries flowed unchecked into local water supplies. In I968, sixty-six percent of the GDR's waterways were "inadmissibly polluted" in industrial centers. ${ }^{79}$ Water became undrinkable in many districts, though most especially in Halle, and officials privately admitted that they had failed to properly care for its citizens' wellbeing. By 1980, classified reports from scientists warned that one-and-a-half million East Germans consumed drinking water that had an "impermissibly high level of nitrates" and which could have dangerous effects on the health of over 30,000 pregnant women and children. The administrative areas with the worst water quality (Potsdam, Dresden, Leipzig Erfurt and Karl-Marx-Stadt) comprised nearly a third of the districts in the GDR and well over a third of the population. ${ }^{80}$ This strong reproach was removed from the final draft of the report, which merely commented on unacceptably high nitrate levels.

Chemical fertilizers posed yet another set of water pollution problems with wide-ranging implications. Used in high volumes in industrial agriculture, run-off from fertilizers dumped nitrates into the ground and water supply. As with other products of the chemical industry, it made the water undrinkable. The Office for Water Management, and later the environmental ministry, admitted that its water purification plants were incapable of cleaning water sufficiently to make it potable. ${ }^{8 \mathrm{I}}$ These fertilizers also

77 BArch DK 5/5III, "Ergebnisse und Probleme beim Umweltschutz 1984."

${ }_{78}$ Rubin, Synthetic Socialism, 87.

79 BArch DC 20-I/3/715, "Prognose: Industrielle Abprodukte und planmäßige Gestaltung einer sozialistischen Landeskultur in der DDR," 1968.

8o BArch DK 5/2145, "Bericht über Ergebnisse des Umweltschutzes in der Deutschen Demokratischen Republik, 198I."

${ }^{81}$ BArch DK 5/5155, "Information über die Durchführung eines RGW-Symposiums zu theoretischen und technisch-ökonomischen Fragen abproduktarmer und abproduktfreier Technologien vom I5. bis I9. März 1976 in Dresden.” 
leached the soil of its nutrients, making the soil less fertile and less productive over time, and even poisoning pig and livestock populations. ${ }^{82}$ Rivers and lakes became so polluted that officials forbade swimming even in nature preserves. In many places where it was not forbidden, East Germans simply considered it dangerous. ${ }^{83}$ The industrial agriculture that fed the East German people in turn poisoned them with highly salinized water. These forms of contamination and more frustrated the general population, casting a pall on overall quality of life in the GDR just as western standards of living took off in comparison.

Given the GDR's small size, it is unsurprising that water pollution transcended borders, connecting the two Germanys. In central Europe, rivers disproportionately flow from east to west, which carried East German water pollution into the FRG. Fifty-two waterways crossed the German-German border, connecting the rival states even as they sought to politically distance themselves. ${ }^{84}$ From the I950s onward, pollution from the GDR - and in some cases even Czechoslovakia - caused an outcry on the other side of the Iron Curtain. Swimming in the Elbe River in and around Hamburg was inadvisable, while dead fish regularly floated to the top after East German chemical spills. ${ }^{85}$ As the GDR confronted the challenges of industrial production, it was intimately tied to neighboring countries through environmental problems that necessitated negotiations and agreements.

Early on, East German officials recognized the transboundary character of their industrial pollution, and in order to resolve it, experts created a common set of environmental knowledge. Scientists and diplomats worked to reduce air pollution in the tri-border region known as the Black Triangle, where the GDR, Poland, and Czechoslovakia met. ${ }^{86}$ Emissions far exceeded legal caps there, precipitating a host of health problems for residents as well as damaging forests in all three countries. Especially lignite mining and power plants in East German Lusatia and

${ }^{82}$ Thomas Fleischman, Communist Pigs: An Animal History of East Germany's Rise and Fall (Seattle, WA: University of Washington Press, 2020), 85-88.

${ }^{83}$ RHG RG/B I8, "Brief an Freunde von den Umweltblättern," July Io, I989.

${ }^{84}$ Tim Grady, "A Shared Environment: German-German Relations along the Border, 1945-1972," Journal of Contemporary History 50, no. 3 (July 2015), 66I. For more on the history of the Elbe, see Dirk Schubert, "Path Dependencies Managing the River Elbe and the Requirements of Hamburg's Open Tidal Seaport" in Rivers Lost, Rivers Regained: Rethinking City-River Relations, eds. Martin Knoll, Uwe Lübken, and Dieter Schott (Pittsburgh, PA: University of Pittsburgh Press, 2017), I57-I58.

${ }^{85}$ Grady, "A Shared Environment," 667.

86 The Black Triangle's pollution was both a matter of natural resource deposits and the region's relatively peripheral location in each of the three countries. 
Polish Lower Silesia became a point of contention in the 1960s and 1970s. ${ }^{87}$ Moreover, water pollution from Czechoslovakia had downstream effects on Poland and the GDR. Experts in the three countries clearly understood the transnational impact of pollution and viewed environmental protection as a project that "bound together socialist countries," physically and ideologically. ${ }^{88}$

The GDR's border with Poland also raised numerous natural resource concerns. For pragmatic, resource-related and idealistic reasons, Poland and the GDR signed a number of treaties and collaborated on various projects, including shared water and coastlines. The Oder and Neisse Rivers garnered attention because the border ran through them and both sides drew water for their own needs. ${ }^{89}$ The two countries had cooperated on pollution in waterways since a Polish law on water quality had been set in 1961. ${ }^{90}$ They signed another agreement about the Oder and Neisse in 1965, with both states then settling on specifics about what constituted navigable waters and who had access to them in 1969. The last of these agreements clarified that neither party could alter the course of the waterways so as to hinder the other. They had to "maintain the border waters in their appropriate conditions" by not permitting "physical, chemical, or bacterial contamination" of the Oder or Neisse via waters that flowed into those rivers. ${ }^{9 \mathrm{I}}$ While primarily focused on the economic impact of the pollution, the agreement also acknowledged the need for cooperation when it came to limited yet crucial natural resources.

All of this multifaceted environmental degradation and its impacts on the GDR and East Germans were compiled in the 1968 "prognosis report" that motivated the SED to act. The report's findings, which Werner Titel and his colleagues collected, exposed the many ways that pollution imperiled the GDR's interests at home - such as economic growth and social welfare - as well as its international reception. The public health consequences alone cost the economy, and by extension the state, valuable

87 BArch DK 5/I83I, Wambutt, "Information über den Stand und die Entwicklung des Umweltschutzes in der DDR," April 5, 1972, Io.

88 Ibid., I8-I9.

89 BArch DK 5/5972, "Vereinbarung zwischen der Regierung der DDR und dem Bevollmächtigten der Regierung der VRP über die Zusammenarbeit auf dem Gebiet der Wasserwirtschaft an den Grenzgewässern zur Vorbeugung und Bekämpfung außergewöhnlicher Verunreinigungen der Grenzgewässer," I989.

90 BArch DK 5/6064, "Gesetz vom 3I. Januar 196I über den Schutz der Gewässer vor Verunreinigung," Quelle: poln. Gesetzestext.

9I BArch DK 5/5972, "Vereinbarung zwischen der Regierung der Deutschen Demokratischen Republik und der Regierung der Republik Polen über die Schiffahrt auf den Grenzgewässern und über die Ausnutzung und Instandhaltung der Grenzgewässer,” 1969. 
resources. Smoke, particulate matter, and gases caused illnesses of the respiratory tract, eyes and skin, which compromised workers' health..$^{22}$ Moreover, polluted water endangered both domestic consumption and industrial production in addition to swimming, recreation, and nature conservation, all of which the SED purported to support for East Germans' overall wellbeing. ${ }^{93}$ When citizens of a workers' state could barely breathe much less drink clean water or recreate outdoors, the SED realized it was more difficult for the people to be productive and build socialism. The report concluded that the social benefits of investing in regulation were decidedly higher than the numbers alone indicated; environmental protection constituted a component of the social contract between the state and its worker-citizens.

Titel and his colleagues further laid out the international implications of the GDR's pollution, noting above all Moscow's support for increased regulation. In the I96os, Soviet leader Leonid Brezhnev also realized the need to use natural resources more prudently, claiming "all that is our very own communist mission." Other Soviet bloc states had also begun to implement new conservation laws, such as one in Bulgaria that reflected "not only traditional nature protection" but a broader understanding of the interconnectedness of ecological systems. In the nonsocialist world, Titel and the other authors worried that countries such as Sweden were already taking the lead in environmental protection and leaving the GDR behind. ${ }^{94}$ The GDR's economic and environmental situation had cascading effects on society, political decisions, and diplomacy, forcing the SED to reconsider its priorities by the late 1960s.

\section{Institutionalization}

In recognizing environmental devastation, the SED reapplied socialism's mission of improving workers' lives to the protection of nature. As in other arenas, the SED sought to employ science and technological innovation to use resources ever more efficiently for industrial production so that nature could be left as a space for the workers to recreate. The party and state formalized this approach to environmental protection in a range of laws, state institutions, and mass social organizations. These measures addressed

$9^{2}$ BArch DC 20-I/3/7I5, "Prognose: Industrielle Abprodukte und planmäßige Gestaltung einer sozialistischen Landeskultur in der DDR," I968.

93 Ibid.

94 BArch DC 20-I/3/7I5, "Prognose: Industrielle Abprodukte und planmäßige Gestaltung einer sozialistischen Landeskultur in der DDR,” I968, 7. 
the harm to nature in the GDR while leveraging the actions for external audiences. ${ }^{95}$ Intended or not, the SED's support for protection ultimately cultivated popular investment in nature in the years following 1968 and set an expectation that East Germans deserved a clean environment.

A few months before the prognosis report was officially completed, the SED had already included the workers' right (and responsibility) to protect nature in the new constitution. The new law also reinforced more conventional forms of conservation and the preservation of plants and animals. ${ }^{96}$ This inclusion served multiple purposes. It aimed to ameliorate existing conditions within the GDR by inspiring East German citizens to take better care of their natural surroundings as a task for the "entire society." ${ }^{97}$ This tactic naturally obfuscated the fact that state-determined industrial production contributed significantly more to pollution than individual actions. Yet, from an optics standpoint, the constitutional right was also a calculation targeted at the capitalist west, which faced growing environmental protests at the same time. By inscribing protection in its constitution, the East German state sought favor at home and to discredit capitalism abroad.

The SED intended to signal the conviction that it could provide for its citizens and expand the place of nature in the GDR. The constitution used familiar language but also spoke more broadly of Landeskultur, which incorporated a sense of developing or cultivating the land along with engendering a national identity through nature. The constitution stated the need to keep the air and water clean and for the protection of plant and animal life and the beauty of the Heimat. ${ }^{98}$ With these statements, the SED leadership blended older ideas about preserving the natural landscape with considerations about preventing water and air pollution. Yet the terms "environment" or "environmental protection" did not appear in the constitution. They first appeared in official documents a year or two later. This "conservation plus" mentality accounted for the challenges that

95 Newer works that focus on the GDR have begun to integrate domestic and international implications but tend to focus either on one side or the other, such as Moranda, The People's Own Landscape, II6-I26, or Dix and Gudermann's "Naturschutz in der DDR." Others have focused on the international side, such as Kai Hünemörder, "Environmental Crisis and Soft Politics: Détente and the Global Environment, 1968-1975," in Environmental Histories of the Cold War, eds. J.R. McNeill and Corinna R. Unger (New York: Cambridge University Press, 2010), 257-276, and Chaney and Gudermann, "The East's Contribution to International Conservation Part I."

${ }^{6}$ Artikel I5, Absatz 2, Verfassung der Deutschen Demokratischen Republik, 1968.

97 BArch DK 5/4454, "Entwurf: Prognostische Grundlagen über die Entwicklung von Hauptrichtungen des Umweltschutzes," I973.

${ }_{98}$ Artikel 15, Absatz 2, Verfassung der Deutschen Demokratischen Republik, 1968. 
the smokestack industrial economy generated but framed them in familiar and anthropocentric terms (i.e. "what can nature do for us," rather than seeing the environment as an integrated whole)..$^{99}$

The 1968 constitution marked a turning point in the dynamic between the economy and ecology, restricting the ways in which nature could be used. ${ }^{100}$ This formulation stated that the GDR's "precious natural riches" must be protected and used efficiently, and it incorporated stronger language than the 1954 Conservation Law. The constitution stipulated, for instance, that land designated for agriculture or forestry could only be used for its intended purpose. The SED's embrace of nature acknowledged domestic concerns and signaled to East Germans that nature mattered to the leadership and ought to matter to them, too. At the same time, the constitution made a statement to the rest of the world. In the GDR's pursuit of recognition in a Cold War context, the SED hoped that being at the front of the environmental charge would curry favor beyond the borders of the GDR. This progressiveness was to speak to the benefits of socialism and stand in contrast to capitalist, imperialist countries in the west that refused to regulate industry.

Two years later, the Council of Ministers issued the Landeskultur Law to implement the constitutional promises, revealing a continuing evolution in official thinking. The law used hybrid language that both relied on traditional Heimat and resource conservation language as well as an evolving understanding of the term "environment" that treated humans and nature as part of a single, interconnected system. Still, in nearly all cases, either "natural" or "human" preceded the term, suggesting the law's authors failed to truly view humans and nature as truly interdependent. The law admitted that humans had an impact on the environment but still framed it as an object that could be shaped or constructed, a mentality reflecting the SED's worldview that anything and everything could be (re) built in a socialist society. ${ }^{\mathrm{IOI}}$ Natural riches were to be used prudently and economically, while at the same time industry and society were to work together to protect the socialist Heimat for current and future generations. ${ }^{\text {IO2 }}$ The SED sought to reconcile these many demands on nature through a scientific and technical revolution that would allow the

99 Dix and Gudermann, "Naturschutz in der DDR," 572.

Iо० Artikel I5, Absatz I, Verfassung der Deutschen Demokratischen Republik, 1968.

${ }^{\text {Ior }}$ II. Gestaltung und Pflege der Landschaft sowie Schutz der heimatlichen Natur, $₫$ Io Zielstellung Gesetz über die planmäßige Gestaltung der sozialistischen Landeskultur in der Deutschen Demokratischen Repbulik_Landeskulturgesetz—vom I4. Mai 1970.

Io2 Ibid., Präambel. 
economy to use resources ever more efficiently while leaving the rest as a place for workers.

The Landeskultur Law and its subordinate decrees demonstrated the SED's ongoing mediation between the needs of the economy and environmental protection. They included a combination of practical topics, such as noise pollution and sanitation, but also the conservation of plants and animals, and the "protection and care of the socialist national culture." The last of the four decrees specifically replaced the 1954 Conservation Law, because the old law ignored the "social demands on the complex development of the [natural] landscape." It placed conservation in a broader context, tying it to socialist Landeskultur while also arguing that protecting the environment was essential for both the citizens' wellbeing and the continued growth of the economy. ${ }^{\text {IO3 }}$ Nevertheless, the Landeskultur Law determined that the Council of Ministers had the responsibility to decide which interests should be given priority," permitting the leadership to place the economy over the environment. ${ }^{\mathrm{IO}}$

The challenge of navigating these two charges distinguished environmental protection under communism from western movements. Green movements under capitalism were explicitly protest movements, which called attention to industrial pollution, and to the governments that hesitated to regulate. The green movements did not need to legislate or consider the economic stance; they merely had to protest. The SED, however, walked a fine line between promising protections without criticizing its own industries and the pollution they generated. In trying to prove that socialism was more progressive and inclusive than the capitalist west, the SED became tangled in a web of being both polluter and protector. Environmental protection was more than a political talking point for the SED, but it faced an inherent contradiction that it struggled to reconcile.

Despite the SED's divided loyalties between economy and ecology, the SED persevered, approving a Ministry for Environmental Protection and Water Management (MUW) in late I97I. Dr. Werner Titel, the point person for the 1968 prognosis report, became its first minister. A relatively young man, born in I93I, Titel had recently received his doctorate in agricultural science from Humboldt University in 1965. In 1967, he became a member of the People's Chamber and one of many deputy chairs in the

${ }^{103}$ BArch DC 20/I/3/744, "Begründung des Gesetzes," Ministerrat Sitzung vom 1969.

${ }^{104}$ Artikel I, Absatz 3, Landeskulturgesetz, May 1970. Joachim Radkau, The Age of Ecology: A Global History, trans. Patrick Camiller (Malden, MA: Polity Press, 20I4), 368. 
Council of Ministers. In 1969, he became intimately involved in the writing of the Landeskultur Law. It followed logically that he assume leadership of the ministry in November 197I, even before it officially opened. ${ }^{\text {IOS }}$ When Titel suddenly died of a heart attack at the age of forty on Christmas Day 1971, Hans Reichelt was tapped to lead the MUW when it was established in early $1972 .{ }^{106}$ Reichelt remained in that position from the ministry's founding until January I990, navigating economic and environmental interests. ${ }^{\mathrm{IO7}}$

Reichelt guided the MUW's transition from using the concept of Landeskultur to a newer formulation of "socialist environmental protection" (sozialistischer Umweltschutz). He had served as the Minister for Agriculture and Forestry and then as a deputy minister for Agriculture, Forestry, and Foodstuffs Economy, before taking charge of the MUW for virtually the rest of the GDR's existence. ${ }^{\mathrm{I}}{ }^{8}$ The transition to socialist environmental protection drew on Titel's balance between the material needs of the economy with the improvement of citizens' working and living conditions. It went further, however, to incorporate scientific and technological developments that would "strengthen and defend the power of socialism in contrast to the aggressive intention of imperialism." Socialist progress and innovation would solve economic and environmental challenges, because it rationally applied a plan to the problems at hand. In the early I970s, SED officials maintained that socialism and a planned economy could provide both environmental protection and economic

Ios Huff, Natur und Industrie im Sozialismus, I74.

Iо6 “Werner Titel," Wer war wer in der DDR?, http://bundesstiftung-aufarbeitung.de/wer-war-wer-in-derddr-\%2363\%3B-I424.html?ID=3547, accessed February I2, 20I4. "Dr. Werner Titel Verstorben," Neues Deutschland, December 27, I971, I. BArch DK 5/5155, "Mitteilung," April I4, I976.

107 BArch DC 20/I-3/932, "Reichelt, Hans. Kurzbiographie," January 26, I972. Reichelt had less than ideal socialist credentials but overcame them to rise within the ranks of the SED. Born in I925 to an unwed mother, Reichelt finished school in 1943 and was then drafted into the Wehrmacht. He served in various infantry units and eventually rose to the rank of lieutenant before being caught by the Red Army. Between 1945 and 1949, Reichelt was a Soviet prisoner of war, during which time he attended an antifascist school. Upon his release, Reichelt traveled to the recently founded GDR and became politically active in the SED-backed agrarian party, the Democratic Farmers' Party of Germany (Demokratische Bauernpartei Detuschlands). As opposed to university-trained ecologists, the DBD and the agrarian interests it represented tended to be more pragmatic than idealistic. Huff suggests that the SED was not fully satisfied with Reichelt replacing Titel but had no better alternatives. Huff, Natur und Industrie im Sozialismus, I78.

Io8 "Hans Reichelt," Wer war wer in der DDR?, www.bundesstiftung-aufarbeitung.de/wer-war-wer-inder-ddr-\%2363\%3b-I424.html?ID=2790, accessed January 3I, 2018.

109 BArch DC 20/19IO2, "Die Entwicklung der sozialistischen Landeskultur-Ausdruck der kontinuierlichen Politik der SED zur Gestaltung der entwickelten sozialistischen Gesellschaft," January 20, 197I. 
growth through regulation and the efficient use of resources, a goal the party struggled to meet in subsequent years.

Along with changes in state structures, the SED increased mass social activities that recruited East Germans to engage with the environment and reinforced its importance. In March 1969, before his death, Titel argued for closer coordination between state leadership and the social powers of the Cultural League to underscore the environment's place in socialism. ${ }^{\text {IIO }}$ The Cultural League promptly charged the NHF's Central Commission with organizing campaigns on the district and local levels in order to disseminate information about the constitutional article and to educate East Germans. Projects such as "Nature Conservation Week" and regional "Landscape Days" wove together the familiar notions of Heimat and nature while introducing Landeskultur and socialist environmental protection to participants. ${ }^{\text {III }}$ Typical of the SED's totalizing project, the party sought to realize a utopian and ideological ideal by using mass campaigns and tightly controlled social organizations to educate its citizens.

As the GDR wrestled with the consequences of smokestack industrialization, the SED sought to balance economic and environmental needs for domestic and international audiences. By 1968, the party was moving to support more environmental action on numerous fronts from the legal to the social at home, in the Soviet bloc, and the nonsocialist world. This decision built on existing conservationist traditions while addressing the obvious pollution occurring through socialist idealism. The SED's faith in science and technology to produce a better future created expectations among East Germans in the coming decades. The party and the state proudly proclaimed a socialist environmentalism would prevail, caring for both workers and nature against a Cold War backdrop.

\section{A Global Environmental Moment}

As the SED committed itself to environmental protection, objections to pollution resonated around the world in a larger moment of reckoning. I968 marked both an endogenous East German and a global turning point for environmentalism as conferences and publications raised awareness about the devastating effects of industrialization and consumption across political systems. Most notably for the GDR, environmental - or green issues gained traction in its Cold War rival, the FRG. The GDR therefore

Iо BArch-SAPMO DY 27/5649, “Sozialistische Heimatkunde - Zu den Hauptaufgaben," I97I.

III Ibid. 
intentionally adopted what it considered to be progressive stances in contrast to the FRG and as a reaction to its precarious international standing. At the same time, the GDR also relied on Soviet bloc relations for diplomatic support and deliberately fostered those ties. Poland was particularly important for the GDR because the two states shared both economic systems and joint environmental concerns, such as in the Baltic Sea. A growing recognition of the pollution and its repercussions motivated the GDR - along with the states on either side of it - to seize a global, environmental moment in the late 1960s and early 1970s. Together, these influences explicitly and implicitly shaped East German understandings of the environment, alternately blending and clashing with socialist environmental protection.

Environmental degradation came under scrutiny around the world at the same time - in the rig6os - as in the GDR. With more freedoms in liberal democracies, however, exposés and conferences disseminated information more easily and resonated with worried citizens. Rachel Carson's 1962 Silent Spring sparked outcry in the United States and is generally credited with initiating the modern environmental movement. ${ }^{\text {II }}$ Rather than listing a slew of pollutants and problems, Carson focused on just one, the effects of the pesticide DDT on the food chain that offered one tangible case with a concrete solution. ${ }^{\mathrm{II}}$ Silent Spring illuminated the interconnectedness of the environment, linking problems that had been treated as relatively discrete phenomena before. In the FRG, water and air pollution had already begun to be regulated in the 1950s and early 1960s but gained resonance in the late 1960 s and into the I970s. ${ }^{\text {II }}$ Protests against other pollutants in the air and water, and especially questions about the repercussions of nuclear testing, reached a broader public, slowly compelling governments in western Europe and North America to reconsider their policies and institute regulation. ${ }^{\text {IIS }}$

In 1968, numerous conferences and published works underscored burgeoning international awareness about pollutants, population growth, and consumption. The United Nations' "Man and the Biosphere" conference in 1968 became the first occasion to discuss intergovernmental

${ }^{112}$ Uekötter, The Greenest Nation?, 78-79. Joachim Radkau, Nature and Power: A Global History of the Environment (New York: Cambridge University Press, 2008), 268.

${ }^{113}$ Radkau, Nature and Power, 269.

I14 Jens Ivo Engels, Naturpolitik in der Bundesrepublik: Ideenwelt und politische Verhaltensstile in Naturschutz und Umweltbewegung, 1950-1980 (Paderborn: Ferdinand Schöningh, 2006), 32-33.

IIs Radkau, Nature and Power, 273-275. Radkau and Uekötter complicate this narrative somewhat, demonstrating that certain issues, such as clean air legislation in the FRG, found more resonance in the i95os than around 1970. 
coordination on the impact of humans on the environment. ${ }^{116}$ That same year, Only One Earth and Paul Ehrlich's The Population Bomb illuminated the global impact of seemingly small-scale matters. The Club of Rome also first convened in 1968 as an informal collection of thirty individuals form ten countries to discuss "the present and future predicament of man." A group of experts with different backgrounds - scientists, educators, economists, humanists, industrialists, and civil servants - met to discuss the interdependent character of the "global system in which we all live," publishing the famous Limits to Growth report in $1972 .{ }^{\mathrm{II7}} \mathrm{In}$ it, the authors questioned contemporary rates of consumption and the use of the earth's finite resources. ${ }^{\text {II8 }}$ These works and others like them argued that growing populations, waste and consumption damaged the natural environment. They became a rallying cry for more proactive and coordinated stances.

The student and extra-parliamentary protests of the late 1960s changed the face of both the United States and western Europe. Among other points of contention, such as the U.S. involvement in Vietnam and institutional hierarchy in universities, the environment along with women's rights and peace (and others) spawned a number of interrelated "New Social Movements" (NSMs) in the late 1960s and early I970s. These movements tended to start at the grassroots level and be nonhierarchical, which intentionally stood in opposition to what students viewed as a rigid and old-fashioned society, reflecting a value change on a number of social issues. ${ }^{\text {II }}$ The grassroots and informal character of the NSMs, and their corresponding citizens' initiatives, were very effective in targeting local polluters. Activists protested both against the businesses that produced the pollution and the governments that hesitated to regulate them. ${ }^{20}$ In pushing for more protection, the green movement reshaped and broadened the scope of politics in the FRG, representing roughly half of the three to four thousand citizens' initiatives by the mid-I970s. ${ }^{\text {I2I }}$

The environment also found its way into mainstream media, reflecting broad resonance in West German society and offering the SED the means

\footnotetext{
${ }^{116}$ Michel Batisse, "MAB at age 25," UNESCO Courier 46, no. Io (October I993).

${ }^{117}$ Donella H. Meadows et al., "Forward," in The Limits to Growth: A Report for the Club of Rome's Project on the Predicament of Mankind (New York: Universe Books, I972), 9.

II8 The term we now associate with this is "sustainability," but that term did not come into common usage until after the 1986 Brundtland Report.

II Roland Roth and Dieter Rucht, eds. Neue soziale Bewegungen in der Bundesrepublik Detuschland (Frankfurt: Campus Verlag, 1987), 20.

I20 Radkau, The Age of Ecology, 94-96.

${ }^{\text {I2I }}$ Engels, Naturpolitik in der Bundesrepublik, 20-2I, 326.
} 
to (hypocritically) criticize the west. By 1970, a major weekly news magazine in the FRG, Der Spiegel, led with articles such as "Poisoned Environment," which showcased the impact of pollution on wide swaths of the population. The article began with quotations from Dow Chemical, based primarily in the United States, and then pivoted to challenges in the FRG, including Bonn's intransigence. Despite promises for an action plan in 1970, the interior ministry instead had a "compendium of could, should, and ought to considerations." ${ }^{\text {"22 }}$ It further incorporated warnings in Only One Earth and The Limits to Growth, namely that technological progress and consumption had been fetishized, and called for immediate action. ${ }^{123}$ This combination of government inertia and fear about the future prompted a reconsideration of human interactions with the natural environment in the FRG in the 1970s, spurring protest that the East German leadership sought to exploit. ${ }^{\text {I24 }}$

In this period, environmentalism in the FRG shifted away from earlier conservation and toward an "ecologization" of the movement. ${ }^{\text {I25 Activists }}$ and experts transitioned to treating nature - and human interaction with it - more holistically, recognizing the interconnectedness of biological life and habitat, natural or built. ${ }^{\mathrm{I} 26}$ The term "environment" originated in the United States and was translated as Umwelt in German. Using environment rather than nature reflected the evolution in thinking and was widely used in the West German context. It resonated deeply with individuals who viewed a range of problems, such as nuclear testing and industrial pollution, as part of a larger, complex system, not simply a matter of caring for the landscape. As students protested against the materialism and waste of affluent postwar society, they questioned human interaction with the natural world, the squandering of resources, and the resulting pollution. For them, the broader concept of "environment" became eminently useful. ${ }^{127}$ Building on an internal evolution as well as external influences, the SED slowly adopted "environment" in the early I970s, as the party grew to see nature and resources in a more inclusive and interconnected context.

\footnotetext{
${ }_{122}$ “Morgen kam gestern,” Der Spiegel, October 5, I970, 77. ${ }^{123}$ Ibid., 85.

${ }^{124}$ In the I970s, much of the green movement would focus on the anti-nuclear question. For an evolution of anti-nuclear and environmental activism in the FRG, see Stephen Milder, Greening Democracy: The Anti-Nuclear Movement and Political Environmentalism in West Germany and Beyond, 1968-1983 (New York: Cambridge University Press, 20I7). Dolores Augustine, Taking on Technocracy: Nuclear Power in Germany, 1945 to the Present (New York: Berghahn Books, 2018).

${ }^{\text {I25 }}$ Engels, Naturpolitik in der Bundesrepublik, 294. ${ }^{126}$ Ibid, 295-296.

${ }^{127}$ Sandra Chaney, Nature of the Miracle Years: Conservation in West Germany, 1945-1975 (New York: Berghahn Books, 2008), I76-I77.
} 
West German officials, such as those from the Federal Ministry of the Interior, began to promote the term around 1970 as it expanded regulation. ${ }^{\text {I28 }}$ Like their East German counterparts, they viewed environmental protection as a state-planning project that could be managed through policy, improved technologies, and professional expertise. ${ }^{129}$ Despite different ideological foundations, East and West German officials presented surprisingly similar ideas. Both argued that science and technology, along with planning, would alleviate the degradation both states faced. Typically, western democracies are considered the birthplace of the modern environmental movement, but that interpretation overlooks similar changes in other parts of the world. ${ }^{\mathrm{I} O}$ The parallels between early official reactions to pollution and potential solutions in the FRG and the GDR overlapped more than has been previously acknowledged.

One major difference between the East and West German responses to environmental pollution stemmed from structural differences in the political systems. The green movement in the west opposed the government's stance on pollution and the corporations producing it. The government slowly reconsidered its position and adopted regulations to curb emissions and runoff as it worried about the economic impact it would have on the country. Structurally, the protesters, the government, and the corporations acted independently, each with different decision-making priorities and desired outcomes. In the totalizing system of the East German dictatorship, which lacked an autonomous civil society or market-based economy, the SED shouldered all three roles. ${ }^{\mathrm{I} I \mathrm{I}}$ It called for environmental protection even as it caused the pollution and chose the economy over other considerations. ${ }^{132}$ This contradictory situation eventually proved to be ineffective and led to the rise of an environmental movement outside or at the very least, on the edges - of the dictatorship in the I980s.

Despite the uneasy relationship between conservation and dictatorship, the SED pushed for international engagement - as ever - with the Cold

${ }_{128}$ Engels, Naturpolitik in der Bundesrepublik, 275-276.

${ }^{129}$ Chaney, Nature of the Miracle Years, 177.

${ }^{130}$ Hubertus Knabe, "Neue Soziale Bewegungen im Sozialismus. Zur Genesis alternativer politischer Orientierungen in der DDR," Kölner Zeitschrift für Soziologie und Sozialpsychologie 40, no. 3 (September 1988), 552. Roland Roth and Dieter Rucht, eds., Die sozialen Bewegungen in Deutschland seit 1945: Ein Handbuch (Frankfurt: Campus, 2008).

${ }^{131}$ Jarausch, "Beyond Uniformity," 6. Jürgen Kocka, Civil Society and Dictatorship in Modern Germany (Hanover, NH: University Press of New England, 2010), 2I.

${ }^{132}$ David Blackbourn, The Conquest of Nature: Water, Landscape, and the Making of Modern Germany (New York: W. W. Norton \& Company, 2006), 3II-335, or Uekötter, The Greenest Nation?, I3I-I38. 
War and the GDR's lack of diplomatic status in mind. The GDR lobbied hard and was finally approved for admission to the International Union for Conservation of Nature (IUCN) in 1965, and two years later became one of the founding members of the Eastern Europe Committee. ${ }^{133}$ Though the GDR's involvement was primarily limited to that committee, it still gave the state a foothold on the world conservation stage. Mass social organizations as well as experts contributed to these networks, which were important for strengthening international ties and shaping attitudes toward nature. ${ }^{134}$ As a member of the NHF's Central Commission stated in 1971, "Our socialist Landeskultur is an explicitly political mission, a part of the world-wide struggle between socialism and imperialism." Citizens' environmental activities were imbued with a sense of a greater, socialist purpose.

In 1972, the UN Conference on the Human Environment in Stockholm gathered representatives from both sides of the Iron Curtain who agreed on the importance of solving a global crisis of growth and consumption. ${ }^{135}$ Building on the IUCN's I968 Man and the Biosphere conference, the meeting hosted II3 countries and 400 intergovernmental and nongovernmental organizations. ${ }^{136}$ In the leadup, western countries expected criticism from the Soviet bloc, but the SED refrained, stating the "problems of environmental protection are, according to their nature, universal." ${ }^{\text {'37 }}$ Consistent with the GDR's efforts for diplomatic recognition, the East German leadership - with Titel as the point person until his death worked tirelessly to join the conference, first proposing the GDR participate in $1970 .{ }^{138}$ In a 1971 television interview, Titel emphasized the GDR's enthusiasm for the conference and its readiness to take part in work of environmental protection on an international level. He went so far as to claim lasting security in Europe rested on important joint projects such as protection and that the GDR's inclusion in the Stockholm conference was a precondition for all else. ${ }^{139}$

${ }^{133}$ Dix and Gudermann, "Naturschutz in der DDR," 579.

${ }^{134}$ BArch-SAPMO DY 27/9616, "Zuarbeit zur Rechenschaftsberichten in Vorbereitung des XI. Bundeskongresses des Kulturbundes der DDR," December 3, 1986. Chaney and Gudermann, "The East's Contribution to International Conservation Part I," I2I.

${ }^{135}$ Hünemörder, "Environmental Crisis and Soft Politics," 262.

${ }^{136}$ Chaney, Nature of the Miracle Years, 193.

${ }^{137}$ BArch DC 20-I/3/948, "Vertrauliche Ministerratssache: Beschluß über eine Erklärung der Regierung der Deutschen Demokratischen Republik zur Stockholmer Umweltkonferenz vom I3. März 1972."

${ }^{138}$ Hünemörder, "Environmental Crisis and Soft Politics," 264.

139 BArch DC 20/19093, "Fernsehinterview mit dem Stellvertreter des Vorsitzenden des Ministerrates der DDR, Dr. Werner Titel,” October 27, I97I. 
Despite Titel's grand arguments, the West German Hallstein Doctrine made the GDR's situation precarious. Since the FRG did not recognize the GDR or any country that did, it was ultimately excluded from Stockholm, much to the East German leadership's frustration and chagrin. In a display of solidarity, other communist countries boycotted the conference, too, leaving primarily western countries in attendance. ${ }^{\mathrm{I}}{ }^{40}$ Many of the countries that did participate considered Stockholm a success, and it remained the largest such conference until Rio de Janeiro in 1992, overlooking how many were ignored or excluded. ${ }^{\mathrm{I} I \mathrm{I}}$ The absence of the Soviet bloc and sympathetic countries from Stockholm reinforced a narrative of western environmental commitment and communist neglect. That enduring interpretation ignored both the Soviet bloc's interest in the conference and the FRG's role in creating a situation that made it impossible for the GDR to attend, and by extension, fellow socialist states.

Within the communist bloc, the Soviet Union also admitted how problematic pollution was for the environment and people in the late I960s and early 1970s. ${ }^{\text {I42 }}$ Since Moscow insisted on a degree of uniformity in how the constitutive states operated, communist parties embraced a materialist, production-oriented worldview that shaped their rule. ${ }^{\mathrm{I} 3}$ As Brezhnev began to take the impact of pollution seriously, though, satellite states felt pressure to confront the devastation that their industries caused. ${ }^{\text {I44 }}$ Soviet bloc countries similarly adopted regulation and bolstered mass social conservation associations, though the political situation in each country and its relationship to nature varied the reactions. ${ }^{\mathrm{I} 5}$ Bloc states initiated and participated in conferences on cross-border environmental issues, such as pollution in the Baltic Sea, even though they did not attend Stockholm. Bound both physically by shared pollution and Soviet structures, Poland instituted more regulation in the 1960s and cooperated with East German diplomats and scientists on environmental problems to create a common set of knowledge and solutions. ${ }^{\text {I6 }}$ This program reflected

${ }^{140}$ Uekötter, The Greenest Nation?, 83. $\quad{ }^{\text {I4I }}$ Radkau, Nature and Power, 288.

${ }^{142}$ OSA, "Steps Towards Pollution Control in the USSR," Radio Free Europe, April 6, I972.

${ }^{143}$ Eagle Glassheim, "Ethnic Cleansing, Communism, and Environmental Devastation in Czechoslovakia's Borderlands, 1945-1989," The Journal of Modern History 78, no. I (March 2006), 68

${ }^{\text {I44 }}$ Mark Kramer, "Stalin, Soviet Policy, and the Establishment of a Communist Bloc in Eastern Europe, 194I-1949," in Imposing, Maintaining, and Tearing Open the Iron Curtain: The Cold War and East-Central Europe, 1945-1989, eds. Mark Kramer and Vit Smetana (New York: Lexington Books, 20I4), 26-28.

I45 Barbara Jancar-Webster, "Introduction," in Environmental Action in Eastern Europe, ed. JancarWebster, I-8.

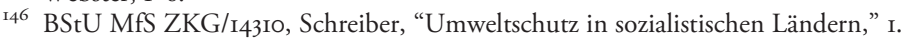


a broader reckoning in Soviet-style communism regarding its relationship to the environment.

As part of these bloc-wide endeavors, Poland expanded its mass social efforts to raise environmental awareness. In the 1960s, the Nature Conservation League (LOP) recruited beyond expert circles to bring in youth organizations and schools. Membership grew dramatically. ${ }^{\text {I47 }}$ In 1968, the PZPR further prioritized the LOP by elevating it to the status of "Association of Higher Interest." Though primarily an honorary promotion, the decision signaled the PZPR's recognition of environmental engagement. ${ }^{\mathrm{I} 8}$ The increased emphasis on popular action and attention to the LOP reflected the Soviet impulse to address resource management, the environment, and public health, into which the GDR also became invested. ${ }^{49}$ In this moment of heightened environmental awareness in the late 1960s, the LOP and the NHF forged deeper friendships according to Soviet wishes, such as jointly declaring their responsibility for the development and protection of the environment through state and society. ${ }^{\text {I5O }}$

This sort of collaboration fed into international efforts to clean up the Baltic Sea. In the 1960s, the GDR and Poland participated in discussions about ameliorating pollution with the United Nations' Economic Commission for Europe, sending delegates to Geneva, Switzerland and Visby, Sweden. The Soviet Union's Minister for Melioration and Water Management, Comrade Borodavchenko, affirmed the importance of the topic with an East German delegation in Moscow in 1969. The USSR planned to publish about the "problem of keeping the Baltic Sea clean," and Borodavchenko wanted the GDR to take up the cause in Geneva the next year. East German and Polish delegations were to actively take part in talks in Visby, coordinating their messages in discussions with capitalist countries in order to maintain a coherent stance. ${ }^{I S I}$ The East German

${ }^{147}$ Olaczek, "Konserwatorska Ochrona Przyrody w Polsce," 88-89. The organization had originally been founded in 1927 during Poland's short-lived interwar democracy and was reestablished under communist control in 1946 as part of the Party's mass social organizations and boasted branches in Warsaw, Lublin, and Gdynia.

${ }^{148}$ Di9680227, "Rozporządzenie Rady Ministrów z dnia 20 sierpnia 1968 r. W sprawie uznania 'Ligi Ochrony Przyrody’ za stowarzyszenie wyższej użyteczności,” http://isap.sejm.gov.pl/isap.nsf/down load.xsp/WDUi9680330227/O/Di9680227.pdf, accessed November 5, 2020.

I49 “Historia Ligi Ochrony Przyrody,” www.lop.org.pl/O_nas, accessed May 3, 202I.

I50 BArch-SAPMO DY 27/5649, quoted in "Sozialistische Heimatkunde - Zu den Hauptaufgaben," I97I.

${ }^{\text {I5I }}$ BArch DK 5/27, "Bericht über die Teilnahme einer Delegation der DDR an der in Visby (Schweden) durchgeführten Konferenz über Maßnahmen zur Verhütung der Verschmutzung der Ostsee," September I0, 1969. 
delegation, though, received instructions to advocate for a treaty to regulate pollution, because only states could properly manage these situations. Yet the delegates were forbidden from making any "binding statements about stipulations of financial provision that pertained to combatting oil pollution in the Baltic Sea." 152 The GDR and Poland supported a treaty to improve conditions, along with the Soviet Union, touting environmental protection but simultaneously limited any concrete commitments.

The Polish and East German approach illustrates the ongoing tension between economy and environment under communism. Experts aspired to be at the vanguard of international environmental protection while expanding industrial production and providing for their citizens at home. These goals pushed the SED and the PZPR to pursue a productionoriented plan, which conflicted with conservationist goals to preserve an untouched nature. The advancement of the economy, especially in highly industrial regions like Silesia, came at the expense of Poles' health and wellbeing. Despite various initiatives, nature conservation and environmental protection did not resonate as strongly in Poland as they did in the GDR, generally remaining within a cohort of scientists and experts. Moreover, the PZPR's response to pollution lacked the GDR's carefully cultivated connections between nature, national identity, and legitimacy. The Polish communists' tenuous hold on the population and a struggling economy added to their difficulties and created a somewhat different model for environmental protection and official activism than in the GDR.

\section{Conclusion}

By 1968, the GDR and countries around the world were forced to reevaluate their relationships with nature, industry, and consumption. The impact of postwar rebuilding and increased production on the environment resulted in a myriad of pollution problems that led to this moment of reckoning. Grounded in traditions of preservation and popular engagement with nature, along with a pragmatic need to manage resources, the SED responded by first embracing conservation and then institutionalizing a specifically socialist environmental protection. The East German leadership viewed these actions as a means of meeting the country's economic needs while advancing its social and diplomatic ambitions.

${ }^{152}$ BArch DK 5/27, "Direktive für die Teilnahme einer im Auftrage der Regierung der DDR entsandten Expertendelegation an einer internationalen Verhandlung zwischen den Ostseeanliegerstaaten zur Vorbereitung des Abschlusses eines Abkommens zum Schutz der Ostsee vor Verunreinigung," undated. 
With a faith in science and technology to utilize natural resources more efficiently, and accordingly, raise productivity, the GDR aimed to improve material living standards alongside preserving a pristine nature. The SED determined that taking on environmental causes could be advantageous in winning over the East German population and demonstrate its progressiveness to the world. The GDR's aim was to gain legitimacy through having East Germans participate in the dictatorship, and in doing so, win the international recognition the SED so desired. ${ }^{153}$

The SED's changing position aligned with a global transformation as governments on both sides of the Iron Curtain came to terms with the toll that pollution took on people and nature. In the west, this anxiety invaded the public consciousness, generating a grassroots movement that pushed democratically elected officials to fix the problems. Additionally, the intellectual freedom of the west spurred an atmosphere of collaboration and mutual concern, which inspired such groups as the Club of Rome and, later, the 1972 Environmental Conference in Stockholm. In the east, however, protection was essentially dictated - and ignored - by the party and the state. In the GDR, the SED sought to make its economy more efficient as well as to paternalistically provide for its workers in a workers' state. The SED investigated the effects of pollution on the people and fostered a broader concept of environmentalism that extended beyond preservation and landscape management projects. Poland and the PZPR similarly reassessed their relationship to nature and joined partnerships with the GDR to address shared problems.

The GDR's treatment of the environment was uniquely situated at the confluence of German traditions of conservation and Soviet style communism. Even as East German officials and experts emphasized the material value of natural resources and focused on conservation, they also incorporated new understandings of the environment in the late rig6os. With the right to a clean environment secured in the constitution and a newly founded ministry, officials touted the GDR's progressiveness time and again over the next twenty years. More than anything, the SED showcased socialism's alleged successes while criticizing governments in the west for being slow to institute regulation. The SED believed that it had much to gain domestically and internationally from environmental protection and institutionalizing in law and through mass social organizations.

${ }^{153}$ Fulbrook, The People's State, I2. 